\title{
Pertussis mortality and public misperceptions
}

$\mathrm{R}$ ecently, after attending a pertussis meeting in Halifax, Nova Scotia, I left Canada via the United States where I passed through immigration.

"Sir, what was the purpose of your trip to Halifax?" the agent asked me.

"I came to attend a whooping cough meeting," I said.

"We don't have any more whooping cough in the US," she said.

"I'm sorry Miss, but yes you have," I replied.

"We did have it years back when I was a child, but not today. Do you mean Sir, that children still get sick of whooping cough?"

She was deeply interested in the topic and even more in my affirmation that children still get sick and die of pertussis, even in the United States. She really couldn't believe that pertussis is still an unresolved public health problem that doesn't respect frontiers or nationalities. Her incredulity was not due to my Spanish accent or English pronunciation, rather it was simply because she couldn't fathom how in this era of advanced medicine and technology, cell phones, emails, wireless laptops, digital cameras, iPods, and Palms, 300000 children still die every year of pertussis, one of the oldest and most common vaccinepreventable diseases.

Finally, I became a bit anxious about our lengthy conversation lest I miss my flight connection. But I didn't want to be rude to her either; as a child I was taught that airport immigration and custom agents should always be respected. Finally, I was able to step away from her desk and proceed to my gate, but I'm grateful to this agent.

She simply expressed what many others probably would have logically thought. "I can't believe babies still die of pertussis. Isn't there a vaccine to prevent that?" she understandably asked, among numerous other questions. "Yes, we have vaccines; however immunity wanes over time," was my

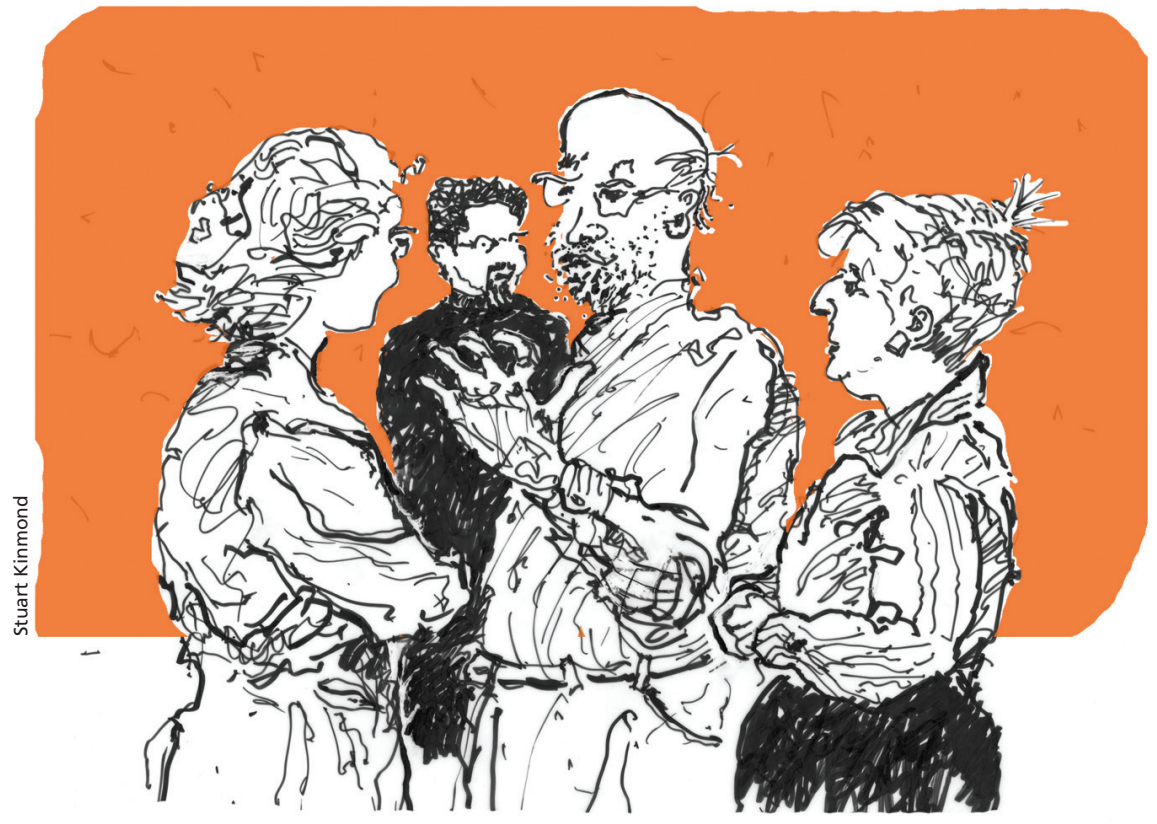

more scientific and evidence-based medicine response.

A pertussis outbreak has affected Costa Rica over the last 2 years, with 16 confirmed infant deaths at our children's hospital. This is exactly the same number reported in a multicentre Canadian surveillance study over the course of 11 years, ${ }^{1}$ and Canada is 195 times bigger than Costa Rica with a population more than 8 times as large. As a former infectious disease fellow in Vancouver, British Columbia, I also saw infants dying of pertussis and witnessed how some parents and doctors lacked information about the magnitude of the problem. Similarly, in one of the few prospective studies ever performed looking at the degree of parental knowledge and awareness about pertussis, we witnessed how much parents and, by extension, society lack basic knowledge about it. ${ }^{2}$ Of concern, only $15.5 \%$ responded correctly that pertussis still exists.

I left Canada that day with many lessons about the misinformation we still have in 2008.

Are we adequately educating and delivering the message to the public about pertussis and its prevention? Definitely not. Let's get into action!

\section{Rolando Ulloa-Gutierrez MD}

Servicio de Infectología Pediátrica

Hospital Nacional de Niños

San José, Costa Rica

Acknowledgement: The author is grateful to Dr. Scott Halperin from the Canadian Center for Vaccinology in Halifax, Nova Scotia.

\section{REFERENCES}

1. Mikelova LK, Halperin SA, Scheifele D, et al. Predictors of death in infants hospitalized with pertussis: a case-control study of 16 pertussis deaths in Canada. J Pediatr 2003;143:576-81.

2. Ulloa-Gutierrez R, Boza R, Umaña MA, et al Parental unawareness, misconceptions, and poor knowledge about pertussis: a contributor to late or misdiagnosis in the developing world? In: 44th Infectious Diseases Society of America's (IDSA) Annual Meeting; 2006 Oct 12-15; Toronto (ON). Abstract 627.

3. Deeks S, De Serres G, Boulianne N, et al. Failure of physicians to consider the diagnosis of pertussis in children. Clin Infect Dis 1999;28:840-6.

Have you got an opinion about this article? Post your views at www.cmaj.ca. Potential Salon contributors are welcome to send a query to salon@ cma.ca. 